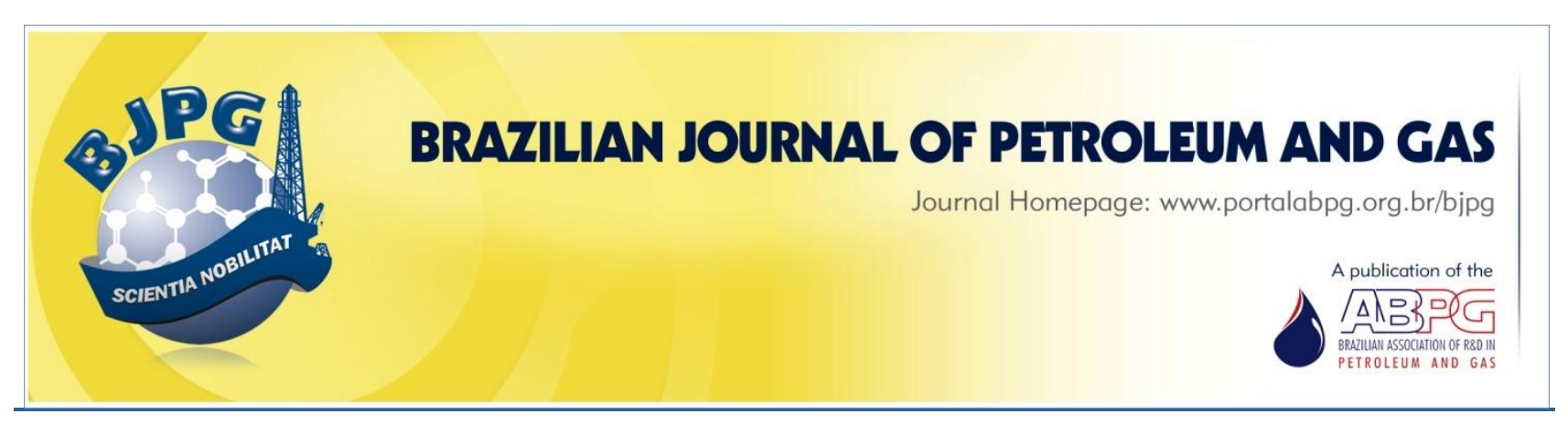

\title{
LIQUID-LIQUID EQUILIBRIUM DATA FOR THE PSEUDO-TERNARY BIODIESEL OF CHICKEN FAT + METHANOL + GLYCEROL
}

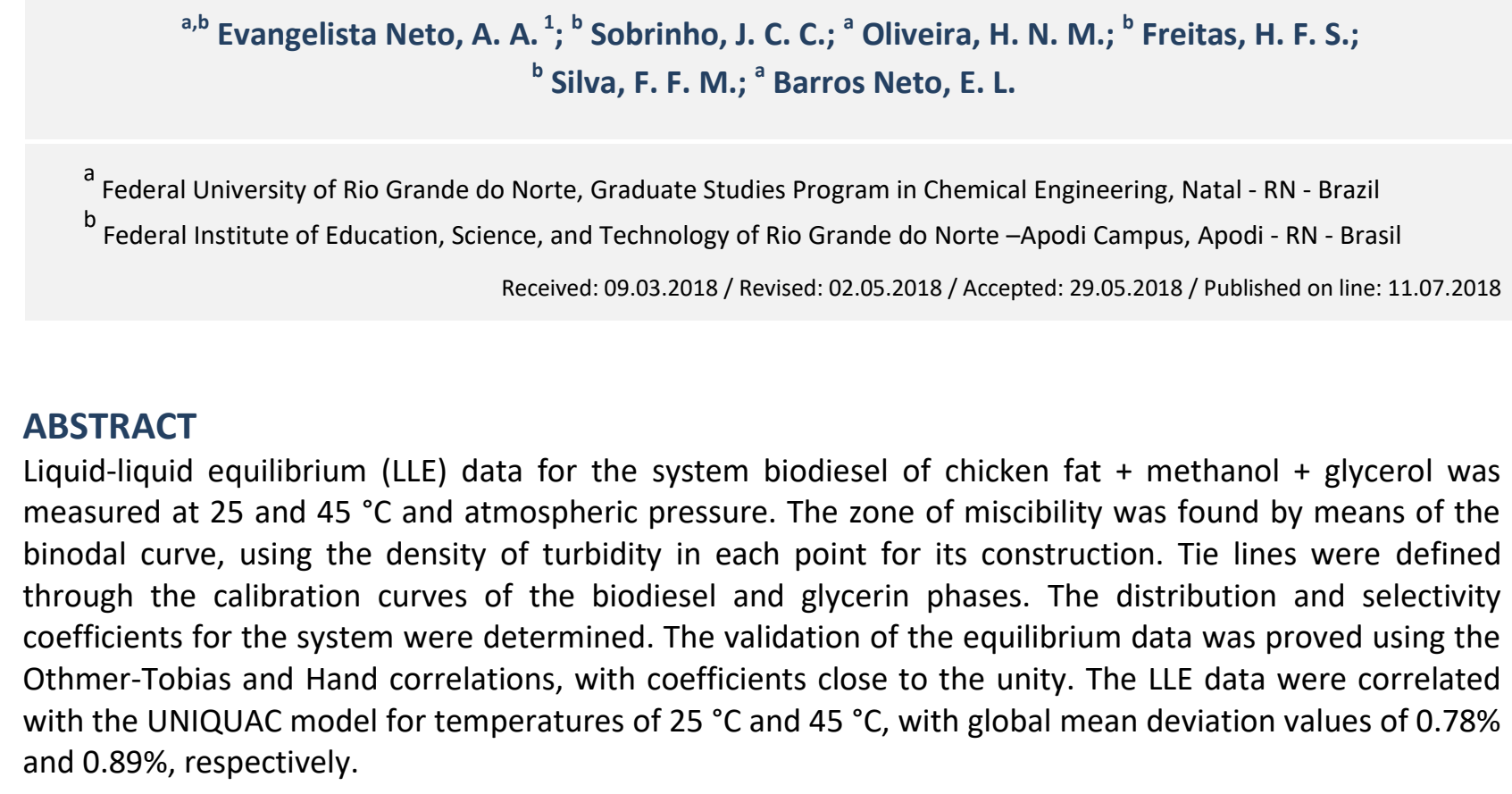

\begin{abstract}
Liquid-liquid equilibrium (LLE) data for the system biodiesel of chicken fat + methanol + glycerol was measured at 25 and $45{ }^{\circ} \mathrm{C}$ and atmospheric pressure. The zone of miscibility was found by means of the binodal curve, using the density of turbidity in each point for its construction. Tie lines were defined through the calibration curves of the biodiesel and glycerin phases. The distribution and selectivity coefficients for the system were determined. The validation of the equilibrium data was proved using the Othmer-Tobias and Hand correlations, with coefficients close to the unity. The LLE data were correlated with the UNIQUAC model for temperatures of $25^{\circ} \mathrm{C}$ and $45^{\circ} \mathrm{C}$, with global mean deviation values of $0.78 \%$ and $0.89 \%$, respectively.
\end{abstract}

\section{KEYWORDS}

liquid-liquid equilibrium; chicken fat biodiesel; methanol; glycerol

\footnotetext{
${ }^{1}$ To whom all correspondence should be addressed.

Address: Federal University of Rio Grande do Norte, Graduate Studies Program in Chemical Engineering, University Campus, Lagoa Nova, Natal/RN, Brazil.

ZIP Code: 59078-970 | Phone: +55 (84) 99937-9509 |e-mail: alcivaneng@hotmail.com doi:10.5419/bjpg2018-0012
} 


\section{INTRODUCTION}

The great dependency on fossil fuels and the consequent environmental pollution are factors that contribute to the increased interest in the search for alternative energies. In this scenario, biofuels appear as a good alternative to using oil. Among the biofuels, there is biodiesel. It has specific properties such as biodegradability, it is non-toxic, and renewable. Its use leads to the reduction of sulfur oxide and greenhouse gas emissions, especially when compared to petroleum fuels (Chuah et al., 2017; Hasan \& Rahman, 2017).

Transesterification is known as the best technique for biodiesel production because the product is chemically similar to conventional diesel fuel (Farobie \& Matsumura, 2017). The process depends mainly on seven parameters: free fatty acid content, type of alcohol used in the reaction and molar ratio (alcohol / oil), type of catalyst and its concentration, reaction time and temperature (Verma \& Sharma, 2016). Therefore, an efficient mix between these reagents becomes crucial for high reaction rates (Tiwari et al., 2018).

The geography of the location and the diversity of raw materials and their respective costs are factors that influence directly the viability of biodiesel production. In an agricultural region this type of fuel can contribute positively to the economy. Therefore, it would be an alternative for use in transportation and in mechanized agriculture (Jain et al., 2018). Other oleaginous plants are potentially producers of biodiesel, but in Brazil, soybeans still represent about $75 \%$ of the raw material for the production of this biofuel (Alves et al., 2017). Therefore, studies with other seeds are necessary for the non-dependence almost exclusively of soybeans, also in view of the competitiveness with the food industry.

Animal fat is also a very important raw material to the production of biodiesel. In Brazil, meat production represents a large portion of the economy and, consequently, it generates fats in significant quantities. Other residual oils, such as fish waste, may also become a good choice for biofuel production. In addition, aquaculture is the animal production sector with the world's highest growth rate, and in 2014 it was responsible for approximately $44 \%$ of fish production worldwide (Roriz et al., 2017). In 2013, Brazil, the fourth largest producer and exporter of pork in the world, had an average herd of 38, 578 million animals (Cherubini et al., 2015). With the trimming during the boning process, a significant amount of pork fat is obtained, and it can become an environmental problem if not handled correctly. Lee et al. (2016) studied the production of biodiesel from swine fat, using the transesterification method, obtaining a yield of $97.2 \%$ at $380{ }^{\circ} \mathrm{C}$. Regarding beef cattle, Brazil has the largest herd of beef in the world, estimated at approximately 200 million animals (Cardoso et al., 2016). As a result, a lot of unused greasy residue is generated and, if it does not have the right destination, it can become a potential polluter.

The production of poultry meat is also of great relevance in Brazil. Consequently, the amounts of waste produced by this activity are also high, in particular, the unused parts of the chicken. According to the Brazilian Association of Animal Protein (Associação Brasileira de Proteína Animal $A B P A)$, in its latest annual report, the production of broiler chickens was $50,524,652$ units, equivalent to 12.9 million tons, of which, $66 \%$ went to the domestic market (ABPA, 2017). Therefore, the production of biodiesel using the viscera of the chicken as raw material is considered of great importance. Literature provides relevant studies on the production of biofuel using the raw material in question. Kirubakaran and Selvan (2018) discussed the importance of fat for energy production, especially high-fat chicken, its advantages for biodiesel production, different forms of fat extraction, and its various techniques. Fayyazi et al. (2015) used an ultrasound system to optimize the production of biodiesel from chicken fat using a genetic algorithm and obtaining the response surface, obtaining a good conversion rate and with biodiesel properties in the ASTM D6751 standard.

The phase equilibrium is very important on the industrial process. In what concerns the production of biodiesel, two partially miscible phases are formed: one rich in glycerin and another, rich in biodiesel. The study of the LLE involving biodiesel produced from animal fat are presented in the literature. Sena and Pereira (2016) studied equilibrium data for the system methylic biodiesel from melon seeds + methanol + biodiesel, presenting suitable data for the tie lines and their respective models. Studies with methylic biodiesel from fish viscera were also analyzed, obtaining good results and a minimal global error in their 
thermodynamic modeling (Maghami et al., 2016). This work reports LLE data for the ternary system composed by biodiesel of chicken fat + methanol + glycerol, at 25 and $45{ }^{\circ} \mathrm{C}$ and atmospheric pressure. Furthermore, UNIQUAC model was applied for correlating experimental data series.

\section{MATERIALS AND METHODS}

\subsection{Reagents}

The reagents used to obtain biodiesel and to obtain the equilibrium data were: melted chicken fat supplied by the city market in Apodi, situated in the state of Rio Grande do Norte (Brazil), methanol (Neon, 99.8\%) glycerol PA (Neon, 99.7\%), potassium hydroxide (Impex, 86\%), and sodium sulfate anhydrous (Sigma-Audrich, 99\%).

\subsection{Biodiesel production}

Initially, since the chicken fat was in solid state, it was necessary to melt it down. Then, the transesterification process began with the preparation of potassium methoxide from potassium hydroxide $(\mathrm{KOH})$ and methanol. To obtain this, $40 \mathrm{~mL}$ of methyl alcohol and $2 \mathrm{~g}$ of potassium hydroxide $(\mathrm{KOH})$ were used under constant stirring until complete homogenization.

The transesterification reaction was carried out by mixing the obtained potassium methoxide to $100 \mathrm{~g}$ of chicken fat in a molar ratio (1:6), at a constant stirring using magnetic plate, showing satisfactory results for the procedure. This reaction mixture was stirred for 60 minutes at room temperature for the transesterification reaction. To get the alkyl esters mixture from excess methanol and glycerol, a separation funnel was applied.
The acidity index obeyed the methodology proposed by Pregnolato and Pascuet (1985) and was obtained by titrimetric methods. The experiment used three Erlenmeyer flasks. During the process, $2 \mathrm{~g}$ of the chicken methyl biodiesel were added to $25 \mathrm{~mL}$ of an ether-alcohol solution (2:1), and 2 drops of the phenolphthalein indicator titrated with the standard solution of $0.1 \mathrm{M} \mathrm{NaOH}$ until the appearance of pink coloration that remained for at least 30 seconds. All procedures were done in triplicate. The value of the acidity index of $0.286 \mathrm{mg}$ of $\mathrm{KOH} / \mathrm{g}$ was satisfactory; considering that the maximum allowed limit is 0.5 $\mathrm{mg}$ of $\mathrm{KOH} / \mathrm{g}$ (ANP, 2014).

\subsection{Gas chromatography}

To determine the composition of the biodiesel produced, gas chromatography coupled to mass spectrometry was performed. The equipment used was the GCMS-QP2010 SE-SHIMADZU, with a $30 \mathrm{~m}$ long capillary column, $0.25 \mathrm{~mm}$ diameter and $0.25 \mu \mathrm{m}$ thickness. The solution was diluted $1 \%$ with acetone and the sample injection was $1 \mu \mathrm{l}$. Helium was used as gas during the operation, with a flow rate of $2 \mathrm{~mL} / \mathrm{min}$. The temperature of the injector was set at $250{ }^{\circ} \mathrm{C}$. Table 1 shows the profile of methyl esters present in the chicken fat methyl biodiesel.

\subsection{Equilibrium data}

A glass cell with magnetic stirring and temperature control was used. The apparatus used to maintain operating temperatures was SP Labor Ultra-Spectacular Bath SP-152. The methodology available through literature was used to obtain the binodal curves (Sena \& Pereira, 2016). Initially, mixtures with known glycerol and methanol compositions were titrated with biodiesel. Each time the cloud point was reached, the

Table 1. Profile of methyl esters in the biodiesel from chicken fat.

\begin{tabular}{lccc}
\hline \multicolumn{1}{c}{ Methyl Esters } & Mass Composition (\%) & Molar Mass (g/mol) & Molecular Formula \\
\hline Methyl tetradecanoate & 0.56 & 242.40 & $\mathrm{C}_{15} \mathrm{H}_{30} \mathrm{O}_{2}$ \\
Methyl Hexadec-9-Enoate & 0.32 & 268.44 & $\mathrm{C}_{17} \mathrm{H}_{34} \mathrm{O}_{2}$ \\
Methyl Palmitoleate & 3.21 & 268.44 & $\mathrm{C}_{17} \mathrm{H}_{34} \mathrm{O}_{2}$ \\
Methyl Palmitate & 22.19 & 270.45 & $\mathrm{C}_{17} \mathrm{H}_{34} \mathrm{O}_{2}$ \\
Methyl Linoleate & 27.06 & 294.47 & $\mathrm{C}_{19} \mathrm{H}_{34} \mathrm{O}_{2}$ \\
Methyl Oleate & 40.91 & 296.49 & $\mathrm{C}_{19} \mathrm{H}_{36} \mathrm{O}_{2}$ \\
Methyl stearate & 5.76 & 298.51 & $\mathrm{C}_{19} \mathrm{H}_{38} \mathrm{O}_{2}$ \\
\hline
\end{tabular}


experimental procedure was stopped and the density of the resulting mixture was measured. Then, the same procedure was performed by titrating with glycerol a previously known mixture of biodiesel and methanol. The densities were taken obeying the same criteria already placed, when the turbidity was detected. All experimental measurements were performed in triplicate. All density measurements were performed using an ANTON PAAR, DMA 35 PORTABLE DENSITY METER, properly calibrated.

With the values of the known densities and compositions for each point, calibration curves were constructed for the three components, both in the glycerin and in the biodiesel rich phase (Sena \& Pereira, 2016). It is noteworthy that the term glycerol is used for the pure compound while glycerin refers to the phase obtained after separation. As the curves found were polynomials of the second degree, one of the roots had to be discarded, considering only one with a physicalchemical sense. With the binodal curves plotted, 6 points below these were chosen, a region that has two phases. A fixed mass of $40 \mathrm{~g}$ for each point, with previously known composition, was used. The mixture was stirred for three hours and allowed to stand for 12 hours, so that phase separation was guaranteed. The whole procedure was performed with temperature control $\left(25^{\circ} \mathrm{C}\right.$ and $\left.45^{\circ} \mathrm{C}\right)$. Then, the densities of the phases rich in biodiesel and glycerin were measured. With the aid of the calibration curves, it was possible to find the values of the tie lines. Both binodal and tie lines curves were plotted using the Python computational tool (Harper et al., 2015), generating diagrams with good quality.

With the values of the tie lines, it was possible to calculate the distribution $\left(\beta_{2}\right.$ and $\left.\beta_{3}\right)$ and selectivity $(S)$ coefficients, which serve to prove the extraction power of the solvent. The calculation of these parameters is represented by equations (1), (2) and (3).

$$
\begin{aligned}
& \beta_{2}=\frac{w_{21}}{w_{23}} \\
& \beta_{3}=\frac{w_{31}}{w_{33}} \\
& S=\frac{\beta_{2}}{\beta_{3}}
\end{aligned}
$$

Where:

$\beta_{2}=$ coefficient of methanol distribution;

$\beta_{3}=$ glycerin distribution coefficient;

$S=$ coefficient of selectivity;

$w_{21}=$ mass fraction of methanol in the biodiesel rich phase;

$w_{23}=$ mass fraction of methanol in the glycerin-rich phase;

$w_{31}=$ mass fraction of glycerin in the biodiesel-rich phase;

$w_{33}=$ mass fraction of glycerin in the glycerol-rich phase.

Then, the Othmer-Tobias and Hand correlations are described by Equations (4) and (5), respectively.

$\ln \left(\frac{1-w_{33}}{w_{33}}\right)=a_{1}+b_{1} \ln \left(\frac{1-w_{11}}{w_{11}}\right)$

$\ln \left(\frac{w_{23}}{w_{33}}\right)=a_{2}+b_{2} \ln \left(\frac{w_{21}}{w_{11}}\right)$

Where:

$w_{11}=$ mass fraction of biodiesel in the biodiesel-rich phase.

\subsection{Application of the thermodynamic model}

With the found experimental data, a classic correlation reported in the literature was used to calculate the compositions, according to each thermodynamic model. The model chosen was UNIQUAC. For this, the Regress computational tool was used (Stragevitch, 1994). The values of the parameters of the UNIQUAC model, $r, q$, and $q^{\prime}$ were found by the sum of the parameters of each subgroup that compose the molecule of each component (Prausnitz, 1999). For the biodiesel, the compounds found in highest concentrations were methyl palmitate, methyl linoleate, and methyl oleate. Each percentage was parameterized, since the other components presented negligible composition. Biodiesel characterization using three constituents (methyl palmitate, methyl linoleate, and methyl oleate) was found to be coherent considering that biodiesel-rich phase is predominantly composed by biodiesel and glycerinrich phase presents biodiesel in dilute concentration. In other words, it is important to 
Table 2. Binodal curve points at $25^{\circ} \mathrm{C}$ and $45^{\circ} \mathrm{C}$ for the biodiesel system of chicken fat $\left(w_{1}\right)+$ methanol $\left(w_{2}\right)+$ glycerol $\left(w_{3}\right)$; compositions are in mass fraction.

\begin{tabular}{|c|c|c|c|c|c|}
\hline \multicolumn{3}{|c|}{$\mathrm{T}=25^{\circ} \mathrm{C}$} & \multicolumn{3}{|c|}{$\mathrm{T}=45^{\circ} \mathrm{C}$} \\
\hline$w_{1}$ & $w_{2}$ & $w_{3}$ & $w_{1}$ & $w_{2}$ & $w_{3}$ \\
\hline 0.0086 & 0.0498 & 0.9416 & 0.0087 & 0.0498 & 0.9415 \\
\hline 0.0171 & 0.0981 & 0.8848 & 0.0171 & 0.0981 & 0.8848 \\
\hline 0.0128 & 0.1975 & 0.7897 & 0.0129 & 0.1975 & 0.7896 \\
\hline 0.0171 & 0.2946 & 0.6883 & 0.0171 & 0.2946 & 0.6883 \\
\hline 0.0086 & 0.3965 & 0.5949 & 0.0086 & 0.3965 & 0.5949 \\
\hline 0.0171 & 0.4917 & 0.4912 & 0.0129 & 0.4938 & 0.4933 \\
\hline 0.0212 & 0.5877 & 0.3911 & 0.0171 & 0.5902 & 0.3927 \\
\hline 0.0171 & 0.6883 & 0.2946 & 0.0337 & 0.6444 & 0.3219 \\
\hline 0.0391 & 0.7378 & 0.2231 & 0.0801 & 0.7201 & 0.1998 \\
\hline 0.0879 & 0.7914 & 0.1207 & 0.9381 & 0.0496 & 0.0123 \\
\hline 0.1843 & 0.7749 & 0.0408 & 0.8893 & 0.0984 & 0.0123 \\
\hline 0.9381 & 0.0496 & 0.0123 & 0.7852 & 0.1964 & 0.0184 \\
\hline 0.8893 & 0.0984 & 0.0123 & 0.6830 & 0.2926 & 0.0244 \\
\hline 0.7852 & 0.1964 & 0.0184 & 0.5924 & 0.3953 & 0.0123 \\
\hline 0.6871 & 0.2945 & 0.0184 & 0.4877 & 0.4879 & 0.0244 \\
\hline 0.5923 & 0.3954 & 0.0123 & 0.3898 & 0.5858 & 0.0244 \\
\hline 0.4937 & 0.4940 & 0.0123 & 0.2877 & 0.6705 & 0.0418 \\
\hline 0.3948 & 0.5929 & 0.0123 & 0.1759 & 0.7034 & 0.1207 \\
\hline 0.2925 & 0.6831 & 0.0244 & $* * * * * * * * * *$ & $* * * * * * * * * *$ & $* * * * * * * * * *$ \\
\hline
\end{tabular}

point out the separation efficiency of the biodiesel constituents in the upper phase. Equations (6) and (7) represent the group contributions UNIFAC structural parameters to the UNIQUAC model:

$r_{i}=\sum_{k} v_{k}^{(i)} R_{k}$

$q_{i}=\sum_{k} v_{k}^{(i)} Q_{k}$

Where:

$i=$ species of the system;

$k=$ identification of subgroups;

$v_{k}^{(i)}=$ number of subgroups of type $k$ in a molecule of species $i$;

$R_{k}=$ value of the UNIFAC volume parameter;

$Q_{k}=$ value of the UNIFAC surface parameter.

\section{RESULTS AND DISCUSSIONS}

\subsection{Binodal curves}

The points of the binodal curves are presented in Table 2 for temperatures of $25^{\circ} \mathrm{C}$ and $45^{\circ} \mathrm{C}$.
Figure 1 shows the arrangements thereof. It is possible to notice a large area with two phases just below the experimental points, characteristic of systems that have biodiesel $\left(w_{1}\right)$, methanol $\left(w_{2}\right)$, and glycerol $\left(w_{3}\right)$ in their mass compositions (Sena \& Pereira, 2016).

Observing Figure 1, one can observe the influence of temperature on the system. The area of miscibility increased when the temperature of $45{ }^{\circ} \mathrm{C}$ was used, when compared to the temperature of $25^{\circ} \mathrm{C}$.

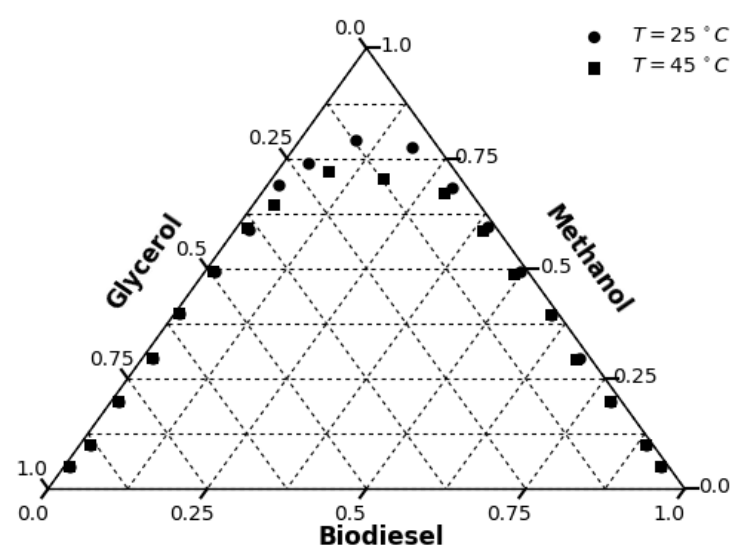

Figure 1. Binodal curves for the biodiesel + methanol + glycerol system at $25^{\circ} \mathrm{C}$ and $45^{\circ} \mathrm{C}$. 
Table 3. Liquid-liquid equilibrium data for the system biodiesel $\left(w_{1}\right)$, glycerol $\left(w_{2}\right)$, and methanol $\left(w_{3}\right)$ at 25 and 45 ${ }^{\circ} \mathrm{C}$; compositions are in mass fraction*.

\begin{tabular}{|c|c|c|c|c|c|c|c|c|c|c|c|}
\hline \multicolumn{6}{|c|}{$\mathrm{T}=25^{\circ} \mathrm{C}$} & \multicolumn{6}{|c|}{$\mathrm{T}=45^{\circ} \mathrm{C}$} \\
\hline \multicolumn{3}{|c|}{ Biodiesel-Rich Phase } & \multicolumn{3}{|c|}{ Glycerol-Rich Phase } & \multicolumn{3}{|c|}{ Biodiesel-Rich Phase } & \multicolumn{3}{|c|}{ Glycerol-Rich Phase } \\
\hline$w_{1}$ & $w_{2}$ & $w_{3}$ & $w_{1}$ & $w_{2}$ & $w_{3}$ & $w_{1}$ & $w_{2}$ & $w_{3}$ & $w_{1}$ & $w_{2}$ & $w_{3}$ \\
\hline 0.8876 & 0.0982 & 0.0142 & 0.0335 & 6675 & 0.2990 & 0.943 & 0.043 & & 0.0586 & .6310 & .3104 \\
\hline 0.8977 & 0.0880 & 0.0143 & 0.02 & 0.5 & & 0.9 & 0.0 & $0 .($ & 0.0 & & \\
\hline 0.9165 & 0.0690 & 0.0145 & 0.0 & 0.4696 & & 0 . & 0. & 0. & 44 & & 599 \\
\hline 0.9176 & 0.0 & 0.01 & 0 & 0.4 & & & & & & & \\
\hline 0.9382 & 0.0470 & 0.01 & 00 & & & 0.9 & 0. & 0.0 & 0.0063 & 06 & 0.6131 \\
\hline 0.9414 & 0.0438 & 0.0148 & 0.0107 & 0.2364 & 0.7529 & 0.9542 & 0.0329 & 0.0129 & 0.0042 & 0.3430 & 0.6528 \\
\hline
\end{tabular}

*The estimated average experimental uncertainty in mass fraction is: $u(w)=0.0005$

Table 4. Parameters of the Othmer-Tobias and Hand correlations at $25^{\circ} \mathrm{C}$ and $45^{\circ} \mathrm{C}$.

\begin{tabular}{ccccccc}
\hline & \multicolumn{3}{c}{$\mathbf{T = 2 5 ^ { \circ } \mathbf { C }}$} & \multicolumn{3}{c}{$\mathbf{T = 4 5}{ }^{\circ} \mathbf{C}$} \\
\cline { 2 - 6 } & $\mathbf{A}$ & $\mathbf{b}$ & $\mathbf{R}^{\mathbf{2}}$ & $\mathbf{a}$ & $\mathbf{b}$ & $\mathbf{R}^{\mathbf{2}}$ \\
$\begin{array}{c}\text { Othmer- } \\
\text { Tobias }\end{array}$ & 0.37 & -2.3567 & 0.9911 & 0.1439 & -2.939 & 0.9936 \\
Hand & & & & & \\
& 0.4528 & -2.5281 & 0.9882 & 0.1986 & -3.23 & 0.9935 \\
\hline
\end{tabular}

\subsection{Tie-lines, distribution, and selectivity coefficients}

Table 3 shows the compositions of the tie lines, both in the glycerin-rich and biodiesel-rich phases, for temperatures of $25{ }^{\circ} \mathrm{C}$ and $45{ }^{\circ} \mathrm{C}$, respectively. With this, it was possible to assemble the diagrams with the tie lines obtained, as can be seen in Figures $2(a)$ and (b).

By the slopes of the tie lines, one can conclude that methanol has more affinity for glycerol than for biodiesel, because hydroxyl $(\mathrm{OH})$ is present in its molecular formula, corroborating with results of Sena \& Pereira (2016). Figures 3 and 4 show the graphs he distribution coefficients and selectivity for temperatures of $25^{\circ} \mathrm{C}$ and $45^{\circ} \mathrm{C}$ with respect to alcohol, in this case, methanol.

The values of selectivity found had values higher than 1, implying a good solvent extraction capacity, in this case methanol, corroborating with Mesquita et al. (2012).

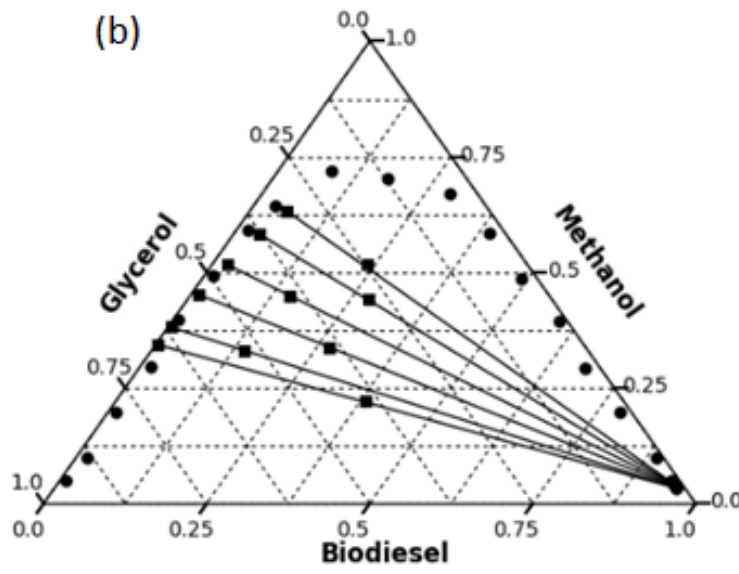

Figure 2. Tie lines for the Chicken fat biodiesel + Methanol+ Glycerol system at (a) $25^{\circ} \mathrm{C}$ and (b) $45^{\circ} \mathrm{C}$. 


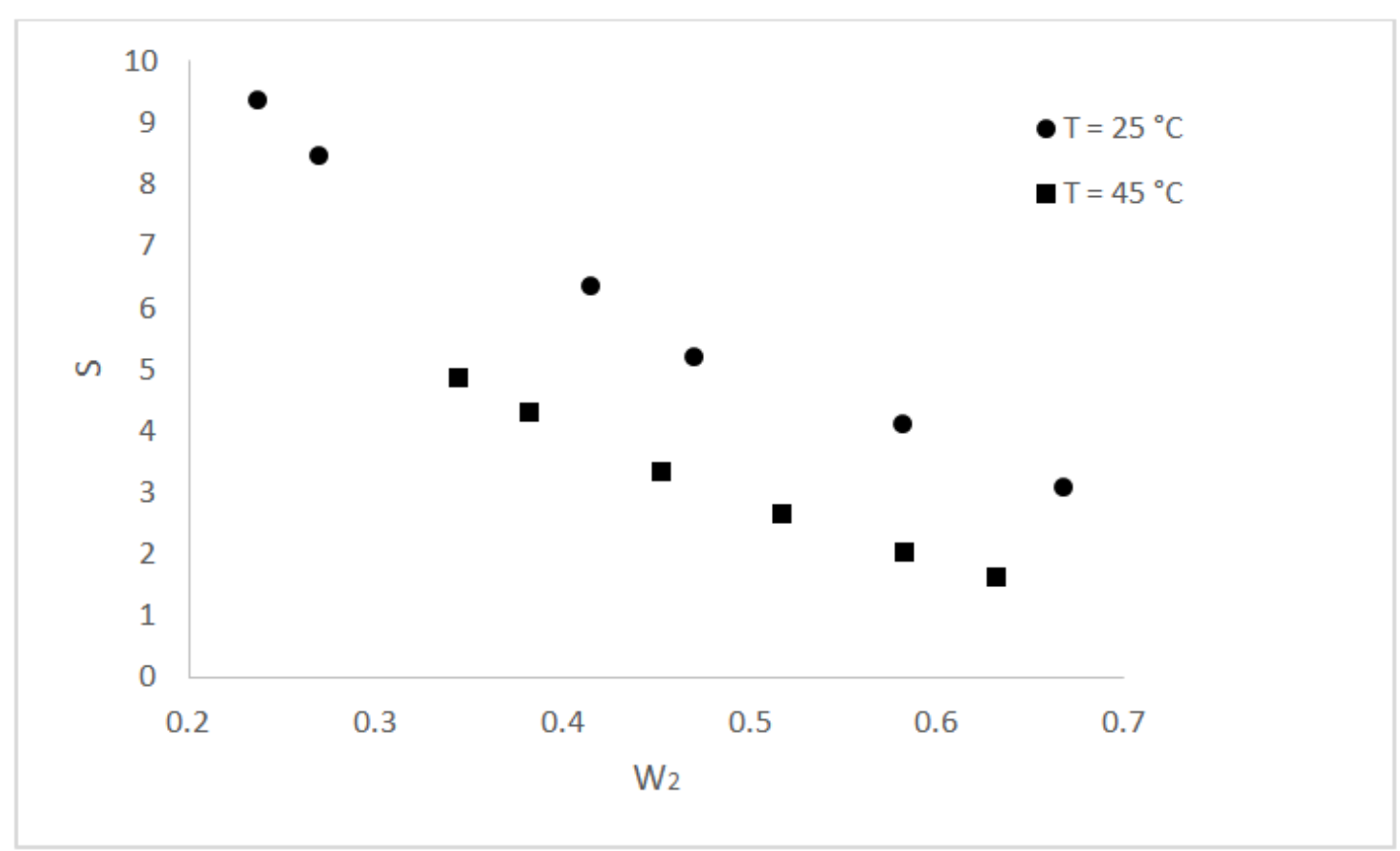

Figure 3. Methanol Selectivity according to their mass fractions $\left(w_{2}\right)$.

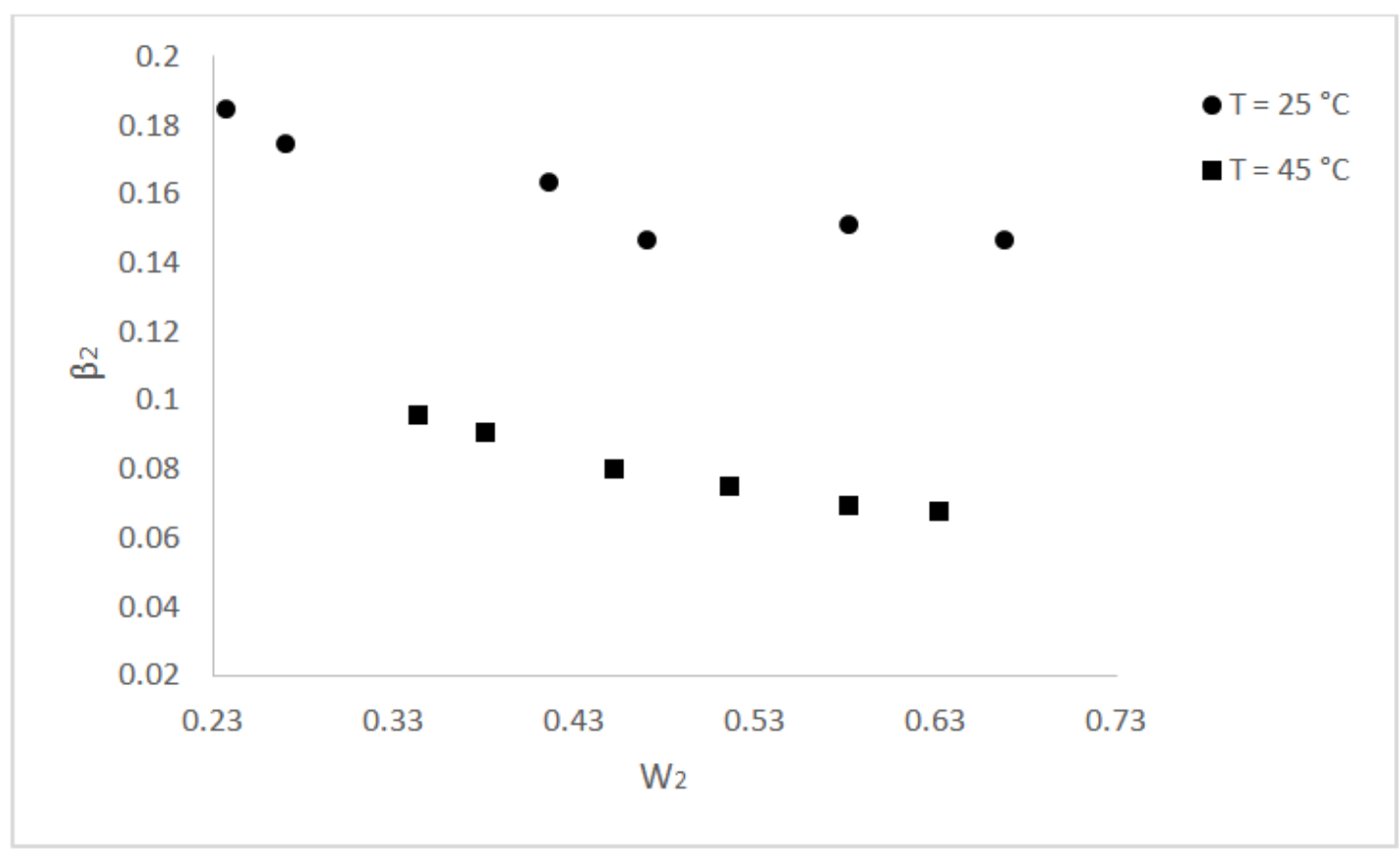

Figure 4. Methanol distribution coefficients according to their mass fractions $\left(w_{2}\right)$.

The reliability of the tie lines was confirmed by the correlations of Othmer-Tobias and Hand. The settings determined for both equations have similar values and are close to the unit. Table 4 presents the parameters found for such correlations. Figures 5 and 6 show the charts relevant to the models. 


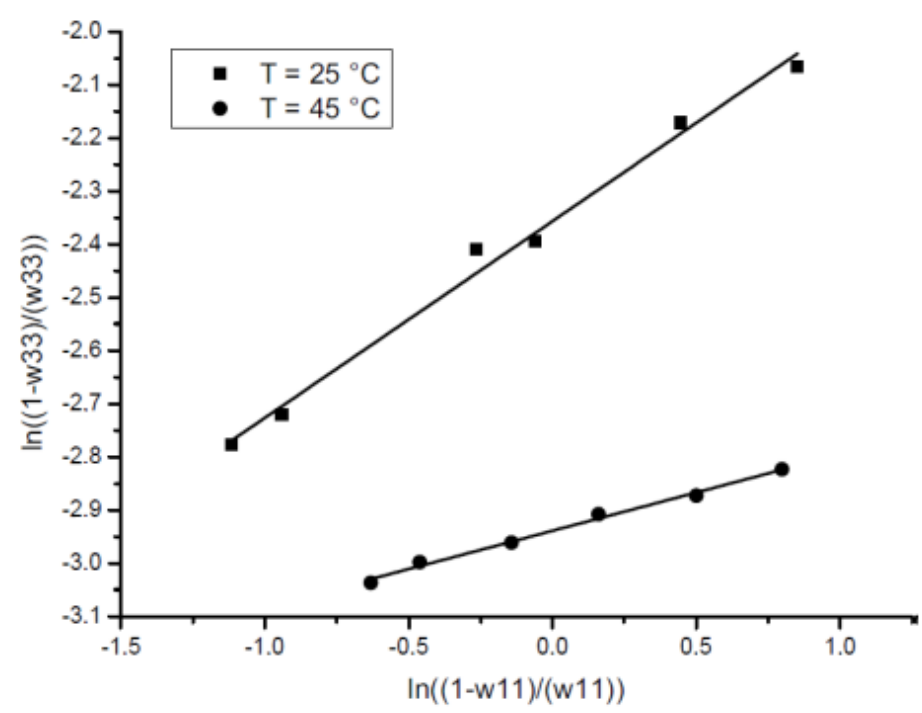

Figure 5. Othmer-Tobias correlation for biodiesel and glycerin rich phases compositions at $25^{\circ} \mathrm{C}$ and $45^{\circ} \mathrm{C}$.

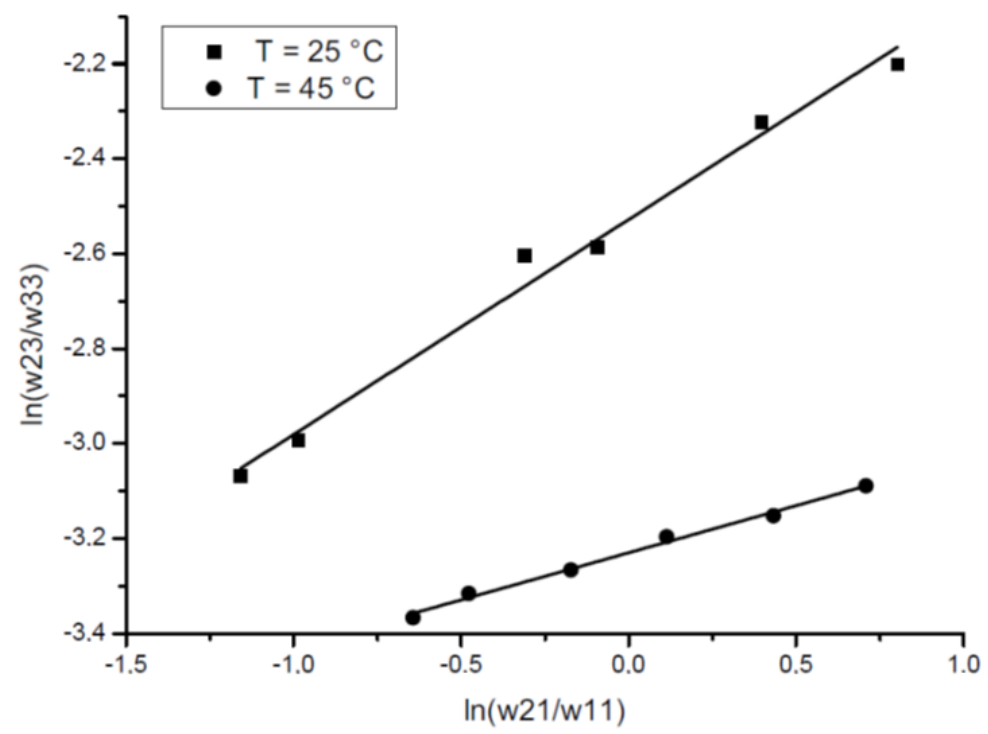

Figure 6. Hand correlation for biodiesel and glycerin rich phases compositions at $25^{\circ} \mathrm{C}$ and $45^{\circ} \mathrm{C}$.

\subsection{Thermodynamic correlation of the experimental data}

The correlation of the experimental data was performed using the UNIQUAC model. The computational tool Regress 2.0 was used for the respective estimations. The values of the structural parameters $r, q$, and $q^{\prime}$ are presented in Table 5 (Prausnitz, 1999). Parameters $A_{i j}$ of the UNIQUAC correlation were estimated and are presented in Table 6. For the biodiesel, the weighted average of the structural parameters was considered, taking into account the mass compositions of palmitic, oleic, and linoleic species. Figures 7 and 8 show the tie lines obtained experimentally and those obtained by each one of the models for temperatures of $25^{\circ} \mathrm{C}$ and $45^{\circ} \mathrm{C}$, respectively.

From the diagrams presented by Figures 7 and 8 , one can see that the UNIQUAC model correlated very well with the experimental data. This is proven by the values of global mean deviations. At $25^{\circ} \mathrm{C}$, the deviation was $0.78 \%$, whereas at $45{ }^{\circ} \mathrm{C}$ the value was $0.89 \%$. 
Table 5. Parameters $r, q$, and $q^{\prime}$.

\begin{tabular}{cccc}
\hline Component & $\mathrm{r}$ & $\mathrm{Q}$ & $\mathrm{q}^{\prime}$ \\
\hline Biodiesel & 12.35 & 10.18 & 10.18 \\
Methanol & 1.4311 & 1.432 & 0.96 \\
Glycerol & 4.7957 & 4.908 & 4.908 \\
\hline
\end{tabular}

Table 6. Parameters $A_{i j}$ (Kelvin) for the UNIQUAC model for biodiesel (1), methanol (2), and glycerol (3).

\begin{tabular}{cccc}
\hline \multicolumn{3}{c}{$\mathbf{T = 2 5 ^ { \circ } \mathbf { C }}$} & \multicolumn{2}{c}{$\mathbf{T = 4 5}{ }^{\circ} \mathbf{C}$} \\
\hline $\mathrm{A}_{12}=239.36$ & $\mathrm{~A}_{21}=442.66$ & $\mathrm{~A}_{12}=620.61$ & $\mathrm{~A}_{21}=277.31$ \\
$\mathrm{~A}_{13}=157.29$ & $\mathrm{~A}_{31}=4.0235$ & $\mathrm{~A}_{13}=140.07$ & $\mathrm{~A}_{31}=31.841$ \\
$\mathrm{~A}_{23}=-35.161$ & $\mathrm{~A}_{32}=75.594$ & $\mathrm{~A}_{23}=118.65$ & $\mathrm{~A}_{32}=-35.247$ \\
\hline
\end{tabular}

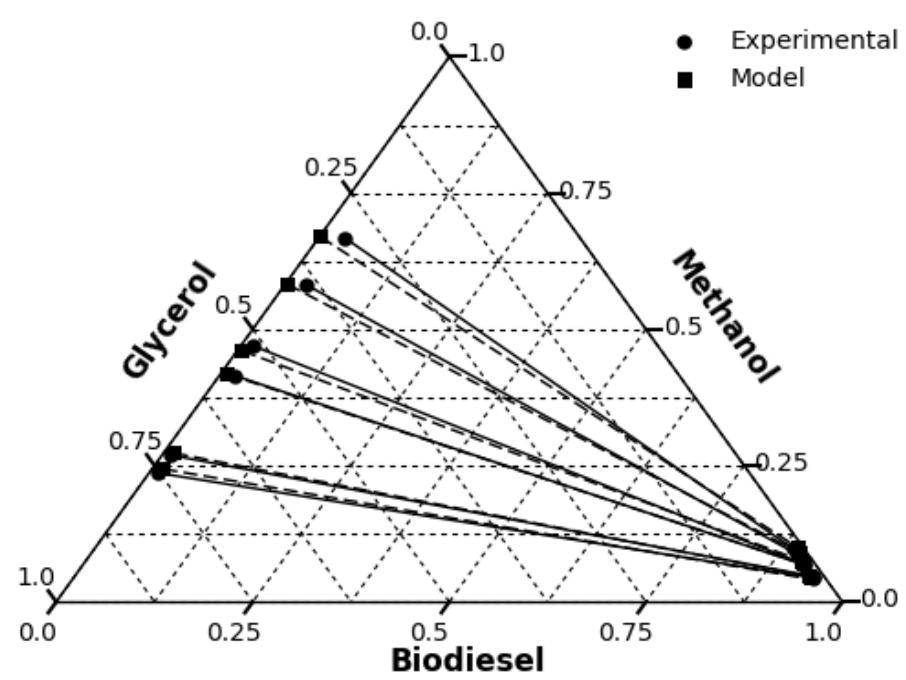

Figure 7. Experimental tie lines predicted by the UNIQUAC model for the biodiesel system of chicken fat + methanol + glycerol at $25^{\circ} \mathrm{C}$.

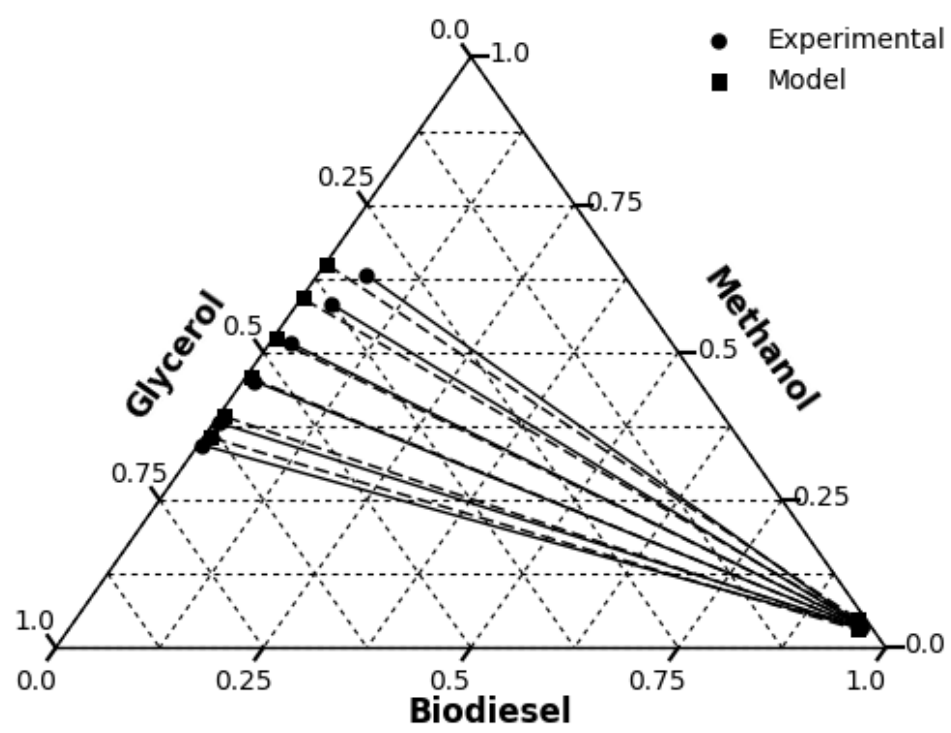

Figure 8. Experimental tie lines predicted by the UNIQUAC model for the biodiesel system of chicken fat + methanol + glycerol at $45^{\circ} \mathrm{C}$. 


\section{CONCLUSIONS}

Biodiesel derived from chicken fat becomes a viable alternative for the production of biofuel given the high amount of waste that the chicken slaughtering activity generates and the fact that Brazil is one of the largest producers of chicken in the world. The LLE data for the system composed by biodiesel of chicken fat + methanol + glycerol presented thermodynamic consistency, as evidenced by the correlations of Othmer-Tobias and Hand. The slope of the tie lines showed that methanol has a better affinity for glycerol than for biodiesel due to the presence of the hydroxyl group. The classic correlation reported in the literature, UNIQUAC, was used for the predictions of tie lines at $25{ }^{\circ} \mathrm{C}$ and $45{ }^{\circ} \mathrm{C}$, with mean global deviation values lower than $1 \%$.

\section{ACKNOWLEDGMENTS}

The authors are grateful to: the Graduate Program in Chemical Engineering (Programa de Pós-Graduação em Engenharia Química - PPGEQ UFRN); Federal Institute of Education, Science and Technology of Rio Grande do Norte - Campus Apodi (Instituto Federal de Educação, Ciência e Tecnologia do Rio Grande do Norte - Campus Apodi); Teaching and Research Center for Petroleum and Gas (NUPEG - UFRN); The National Agency of Petroleum, Natural Gas, and Biofuels (Agência Nacional de Petróleo, Gás Natural e Biocombustíveis - ANP).

\section{REFERENCES}

ABPA - BRAZILIAN ASSOCIATION OF ANIMAL PROTEIN. 2017 Annual Report. Available at: $<$ http://abpa-

br.com.br/storage/files/3678c_final_abpa_relatori o_anual_2016_portugues_web_reduzido.pdf >.

Accessed on: March 2018.

Alves, C. E. S.; Belarmino, L. C.; Padula, A. D. Feedstock diversification for biodiesel production in Brazil: Using the Policy Analysis Matrix (PAM) to evaluate the impact of the PNPB and the economic competitiveness of alternative oilseeds. Energy Policy, v. 109, p. 297-309, 2017.

https://doi.org/10.1016/i.enpol.2017.07.009
ANP - National Agency of Oil, Natural Gas and Biofuels. Biodiesel. 2014. Available in: <http://www.anp.gov.br/biocombustiveis/biodiesel>. Accessed on: May 2018. (in Portuguese)

Cardoso, A. S.; Berndt, A.; Leytem, A.; Alves, B. J. R.; Carvalho, I. N. O.; Soares, L. H. B.; Urquiaga, S.; Boddey, R. M. Impact of the intensification of beef production in Brazil on greenhouse gas emissions and land use. Agricultural Systems, v. 143, p. 8696, 2016. https://doi.org/10.1016/i.agsy.2015.12.007

Cherubini, E.; Zanghelini, M.; Alvarenga, R. A. F.; Franco, D.; Soares, S. R. Life cycle assessment of swine production in Brazil: A comparison of four manure management systems. Journal of Cleaner Production, v. 87, p. 68-77, 2015.

https://doi.org/10.1016/i.jclepro.2014.10.035

Chuah, L. F.; Klemes, J. J.; Yusup, S.; Bokhari, A.; Akbar, M. M. A review of cleaner intensification technologies in biodiesel production. Journal of Cleaner Production, v. 146, p. 181-193, 2017. https://doi.org/10.1016/i.jclepro.2016.05.017

Farobie, O.; Matsumura, Y. State of the art of biodiesel production under supercritical conditions. Progress in Energy and Combustion Science, v. 63, p. 173-203, 2017. https://doi.org/10.1016/i.pecs.2017.08.001

Fayyazi, E.; Ghobadian, B.; Najafi, G.; Hosseinzadeh, B.; Mamat, R.; Hosseinzadeh, J. An ultrasound-assisted system for the optimization of biodiesel production from chicken fat oil using a genetic algorithm and response surface methodology. Ultrasonics Sonochemistry, v. 26, p. 312-330, 2015. https://doi.org/10.1016/j.ultsonch.2015.03.007

Harper, M.; Weinstein, B.; Simon, C.; SwansonHysell, N.; Greco, M.; Zuidhof, G. Python-Ternary: Ternary Plots in Python. Zenodo. 2015. Available at: <https://zenodo.org/record/34938\#.WyKzWuQm6M8>. Acessed on: October 2017

Hasan, M. M.; Rahman, M. M. Performance and emission characteristics of biodiesel-diesel blend and environmental and economic impacts of biodiesel production: A review. Renewable and Sustainable Energy Reviews, v. 74, p. 938-948, 2017. https://doi.org/10.1016/j.rser.2017.03.045 
Jain, M.; Chandrakant, U.; Orsat, V.; Raghavan, $\mathrm{V}$. A review on assessment of biodiesel production methodologies from Calophyllum inophyllum seed oil. Industrial Crops \& Products, v. 114, p. 28-44, 2018. https://doi.org/10.1016/j.indcrop.2018.01.051

Kirubakaran, M.; Selvan, V. A. M. A comprehensive review of low cost biodiesel production from waste chicken fat. Renewable and Sustainable Energy Reviews, v. 82, p. 390-401, 2018. https://doi.org/10.1016/i.rser.2017.09.039

Lee, J.; Tsang, Y. F.; Jung, J. M.; Oh, J. I.; Kim, H. W.; Kwon, E. E. In-situ pyrogenic production of biodiesel from swine fat. Bioresource Technology, v. 220, p. 442-447, 2016.

https://doi.org/10.1016/j.biortech.2016.08.100

Maghami, M.; Seyf, Y.; Sadrameli, S. M.; Haghtalab, A. Liquid-liquid phase equilibrium in ternary mixture of waste fish oil biodieselmethanol-glycerol: Experimental data and thermodynamic modeling, Fluid Phase Equilibria, v. 409, p. 124-130, 2016.

https://doi.org/10.1016/i.fluid.2015.09.046

Mesquita, F. M. R.; Bessa, A. M. M.; Lima, D. D.; Sant'Ana, H. B.; Santiago-Aguiar, R. S. Liquid-liquid equilibria of systems containing cottonseed biodiesel + glycerol + ethanol at 293.15, 313.15 and 333.15K, Fluid Phase Equilibria, v. 318, p. 51-55, 2012. https://doi.org/10.1016/i.fluid.2012.01.016

Prausnitz, J. M.; Lichtenthaler, R. N.; Azevedo, E. G. Molecular thermodynamics of fluid phase equilibria (3rd edition), New Jersey: Prentice-Hall, $1999,860 \mathrm{p}$.
Pregnolato, W.; Pascuet, N. S. Métodos FísicoQuímicos para Análise de Alimentos. São Paulo: Instituto Adolfo Lutz, 1985. 533p. (in Portuguese).

Roriz, G. D.; Delphino, M. K. V. C.; Gardner, I. A.; Gonçalves, V. S. P. Characterization of tilapia farming in net cages at a tropical reservoir in Brazil. Aquaculture Reports, v. 6, p. 43-48, 2017. https://doi.org/10.1016/i.aqrep.2017.03.002

Sena, S. R. C.; Pereira, C. G. Melon seed oil utilization for biodiesel production and analysis of liquid-liquid equilibrium for the system biodiesel + methanol + glycerin. Environmental Progress \& Sustainable Energy, v. 36, p. 1325-332, 2016.

Stragevitch, L. REGREES (Equilibrium data Regression), version 2.0. Chemical Engineering College, UNICAMP, São Paulo, Brazil, 1994.

Tiwari, A.; Rajesh, V. M.; Yadav, S. Biodiesel production in micro-reactors: A review. Energy for Sustainable Development, v. 43, p. 143-161, 2018.

Verma, P.; Sharma, M. P. Review of process parameters for biodiesel production from different feedstocks. Renewable and Sustainable Energy Reviews, v. 62, p. 1063-1071, 2016. https://doi.org/10.1016/i.rser.2016.04.054 